\title{
VEGFR Inhibitor KRN951
}

National Cancer Institute

\section{Source}

National Cancer Institute. VEGFR Inhibitor KRN951. NCI Thesaurus. Code C88267.

An orally bioavailable quinoline-urea derivative inhibitor of vascular endothelial growth factor receptors (VEGFRs) 1 and 2 with potential antiangiogenesis and antineoplastic activities. VEGFR inhibitor KRN951 inhibits VEGF-induced phosphorylation of VEGFRs 1 and 2 , which may result in inhibition of migration, proliferation and survival of endothelial cells, microvessel formation, the inhibition of tumor cell proliferation, and tumor cell death. Expression of VEGFRs may be upregulated in a variety of tumor cell types. 